\title{
Evaluation of a refined surface cover subfactor for use in RUSLE
}

\author{
LAKHDAR BENKOBI, M.J. TRLICA, AND JAMES L. SMITH
}

\begin{abstract}
Authors are research associate, Rocky Mountain Forest and Range Experiment Station, South Dakota School of Mines, 501 E. St. Joe, Rapid City, SD 57701; professor, Range Science Department, Colorado State University, Fort Collins 80523; and professor, Civil Engineering Department, University of Wyoming, Laramie 82071.
\end{abstract}

\begin{abstract}
Concern for nonpoint source pollution from rangelands has increased the need to monitor and predict amounts of soil erosion that may enter streams from adjacent rangelands. This study was undertaken to evaluate a reflned surface cover subfactor (RSC) developed for the revised universal soil loss equation (RUSLE) to simulate soil loss from rangelands as affected by various kinds and amounts of surface cover. In addition, sensitivity analysis indicated which variables most influenced erosion from a sagebrushgrass rangeland (Johnson and Gordon 1988).

Evaluation of the RSC was done by comparing original RUSLE estimates of soil loss with those of RUSLE where the surface cover subfactor (SC) had been replaced with RSC. Estimated soil loss from both simulations were compared with field measurements of soil loss using a simple regression technique. Refined RUSLE predictions of soil loss $\left(r^{2}=0.81\right.$ and 0.50 for dry and moist conditions) were considerably better than those obtained with the original RUSLE model $\left(r^{2}=0.67\right.$ and 0.14 for dry and moist conditions). The refined RUSLE was better at describing Johnson and Gordon (1988) erosion data than was the original RUSLE model. Use of RSC in the RUSLE model may increase its accuracy, but the model still underpredicts the actual amount of soil loss.
\end{abstract}

Key Words: erosion, sediment yield, model evaluation, soil loss, surface cover, water quality

Erosion from rangelands is a major contributor of nonpoint source pollution to streams. This has become a major concern for range managers in the western United States. Soil loss is affected by various abiotic, biotic, and management factors. Rangeland watershed management practices often affect vegetation and ground cover, that in turn influence soil erosion (Sartz and Tolsted 1974, Branson et al. 1981, Foster 1982). Johnson et al. (1980) reported that changes in soil loss for specific sites were almost totally dependent upon changes in soil surface cover. Management of vegetation and litter cover on rangeland is the principal means available to reduce erosion impacts on streams.

Use of the universal soil loss equation (USLE) (Wischmeier and Smith 1978) has not been effective for estimating sheet and rill erosion from rangeland watersheds, as it was developed for use on croplands (Johnson et al. 1980, Trieste and Gifford 1980, Hart 1984, Johnson et al. 1984, Schroeder 1989). The revised USLE (RUSLE) was developed for rangeland purposes (Weltz et al. 1987). However, RUSLE underpredicted actual erosion from a series of plots on 3 different soils in southeastern Arizona (Weltz et

Research was funded by the CSRS Rangeland Competitive Grants Program and the Colorado Agricultural Experiment Station. Authors wish to thank Drs. C.D. Bonham, F.M. Smith, and W.C. Leininger for review of this manuscript.

Manuscript accepted 8 May 1993. al. 1987) and a series of plots at 17 rangelands sites in 7 western states (Renard and Simanton 1990).

The original RUSLE surface cover submodel (SC) is used to estimate soil loss ratio that corresponds to the area of soil covered by mulch (Weltz et al. 1987). This surface cover (SC) is expressed as:

$$
S C=\exp \left[-b * R C *\left(\frac{6}{6+R G}\right)^{0.08}\right],
$$

where $R C$ is the fraction of land covered, $b$ is a coefficient (equal to 0.025 in this study), and RG is a random roughness variable. However, this surface cover subfactor (SC) is based only on total surface cover and, therefore, does not adequately quantify the effects of different cover types and their interactions on soil loss. Recently, Benkobi et al. (1993) developed a refined surface cover subfactor (RSC) to replace the original RUSLE surface cover subfactor (SC). The RSC was developed from laboratory data using a high intensity storm $(100 \mathrm{~mm} / \mathrm{h})$ and a clay loam soil in a controlled experiment. Effects of different surface cover types and amounts, their combinations, and bare ground on soil loss were determined for small plots in this laboratory study using a rotating boom rainfall simulator developed at the University of Wyoming. Cover treatments included vegetation litter, small rocks, and mixtures of these cover types at several levels of cover $(25,50,75$, and $100 \%$ ) and bare ground (control). The regression equation (RSC) derived from these data was expressed as:

$$
\mathrm{RSC}=1-0.82 \mathrm{VL}+0.48 \mathrm{R}-1.23 \mathrm{VL} * \mathrm{R}-1.25 \mathbf{R}^{2} \text {, }
$$

where RSC is the estimated value of the surface cover subfactor (dimensionless), VL is the proportion of cover by vegetation litter, and $R$ is the proportion of cover by rocks (Benkobi et al. 1993).

It was hypothesized that use of this refined surface cover subfactor (RSC) in RUSLE would improve erosion prediction from rangeland watersheds. The purpose of this present research effort was to evaluate RUSLE soil loss predictions for field data, using the refined surface cover subfactor (RSC), and to determine the sensitivity of simulated soil loss with changes in the refined RUSLE model variable values. Soil loss predictions, using both SC and RSC subfactors in RUSLE, were compared with actual erosion measurements for the same field plots (Johnson and Gordon 1988).

\section{Procedures}

Hydrologic data from Johnson and Gordon's (1988) rainfall simulation and erosion study on a sagebrush-grassland range site were used to test the application of the refined surface cover subfactor (RSC) in RUSLE against the original surface cover subfactor (SC). These field data included soil physical characteristics (Table 1), plant canopy cover, ground cover, surface rough- 
Table 1. Soil physical characteristics for interspace areas between sagebrush plants (from Johnson and Gordon 1988).

\begin{tabular}{ll}
\hline \hline Sand (\%) & $37-42$ \\
Silt (\%) & $45-47$ \\
Clay (\%) & $13-16$ \\
Silt \& very fine sand (\%) & $70-72$ \\
Organic matter (\%) & $1.4-2.2$ \\
Permeability index & 3 \\
Soil texture index & 3 \\
\hline
\end{tabular}

ness, slope, simulated rainfall, and soil loss from $1-\mathrm{m}^{2}$ interspace plots (Table 2). Data from sagebrush interspace plots were utilized because the refined surface cover subfactor was developed for surface litter cover, not shrub canopy cover. These plots were located at the Nancy Research Site on the Reynolds Creek Watershed, Ida. Johnson and Gordon (1988) described the interspaces between shrubs as having about $30 \%$ bare soil with clumps of grass and moss that formed a rough surface with shallow depressions caused by repeated animal trampling, frost action, wind, and erosion.

For the present study, as indicated in Table 2, vegetation canopy cover of each experimental plot included live and standing dead material. Vegetation residual cover included live plant material, plant litter, and fine plant residue.

Estimated soil loss (A) was computed for 2 cases: (1) using the original RUSLE (Weltz et al. 1987) in equation 3, and (2) with the refined surface cover subfactor (RSC) in Equation 4 instead of the original surface cover subfactor (SC). Soil loss (A) was estimated by:

$$
A=(E I)(K)(L)(S)(P)(C)
$$

where

$$
\begin{aligned}
A= & \text { estimated soil loss }(\mathrm{t} / \mathrm{ha}), \\
\mathrm{EI}= & \text { individual storm erosivity factor }\left(\mathrm{MJ} \bullet \mathrm{mm}^{-1} /(\mathrm{ha}\right. \\
& \left.\bullet \mathrm{h}^{-1}\right)(\text { Weltz et al. 1987), } \\
\mathbf{K}= & \text { soil erodibility factor }\left(\mathrm{t} \bullet \mathrm{ha}^{-1} \bullet \mathrm{h}^{-1}\right) /\left(\mathrm{ha} \bullet \mathrm{MJ}^{-1}\right. \\
& \left.\bullet \mathrm{mm}^{-1}\right)(\text { Wischmeier and Smith } 1978) \\
\mathbf{L}= & \text { slope length factor, ratio to unit plot, } \\
\mathbf{S}= & \text { slope steepness factor, ratio to unit plot, } \\
\mathbf{P}= & \text { supporting practices factor, ratio to unit plot; } \\
& \mathbf{P}=1 \text { was assumed for this study, and } \\
\mathbf{C}= & \text { cover-management factor, ratio to unit plot. }
\end{aligned}
$$

The factor $C$ is expressed as:

where

$$
\mathrm{C}=(\mathrm{PLU})(\mathrm{CC})(\mathrm{RSC})(\mathrm{SR}) \text {, }
$$

$\mathrm{PLU}=$ prior to land use subfactor, dimensionless,

$\mathrm{CC}=$ plant canopy subfactor, dimensionless,

RSC = refined surface cover subfactor (see Eq. 2), and

$\mathrm{SR}=$ surface roughness subfactor, dimensionless.

Sensitivity analysis was performed to measure the sensitivity of RUSLE model predictions of soil loss with changes in variables values. This analysis also indicated appropriate variables for future investigations that might improve the predictive ability of the model. A Monte Carlo sampling procedure was used to generate the data to conduct the sensitivity analysis (O'Neill et al. 1982, Swartzman and Kaluzny 1987). Variables used for the sensitivity analysis (Table 3 ) were treated as random variables because their

\begin{tabular}{|c|c|c|c|c|c|c|c|c|}
\hline Plot & $\begin{array}{c}\text { Plant canopy } \\
\text { cover }\end{array}$ & $\begin{array}{l}\text { Veg. resid. } \\
\text { cover }\end{array}$ & $\begin{array}{l}\text { Rock } \\
\text { cover }\end{array}$ & $\begin{array}{c}\text { Bare } \\
\text { ground }\end{array}$ & Slope & $\begin{array}{l}\text { Surface } \\
\text { rough. }\end{array}$ & Rainfall & $\begin{array}{l}\text { Soil } \\
\text { loss }\end{array}$ \\
\hline No. & $(\%)$ & $(\%)$ & $(\%)$ & $(\%)$ & $(\%)$ & $(\mathrm{mm})$ & $(\mathrm{mm})$ & (t/ha) \\
\hline N1II 1 & 9.7 & 44.6 & 12.2 & 43.2 & 0.4 & 10.2 & 45.5 & 0.094 \\
\hline N112* & 13.1 & 58.7 & 12.8 & 28.5 & 6.2 & 11.1 & 49.9 & 1.435 \\
\hline N1I3 & 4.0 & 59.0 & 5.6 & 35.4 & 4.4 & 12.5 & 55.6 & 0.232 \\
\hline N2II & 4.6 & 56.2 & 10.1 & 33.7 & 4.7 & 13.2 & 61.1 & 0.339 \\
\hline $\mathrm{N} 2 \mathrm{I} 2$ & 2.0 & 61.9 & 8.8 & 29.3 & 5.6 & 16.2 & 63.9 & 0.394 \\
\hline N2I3 & 4.9 & 60.1 & 4.1 & 35.8 & 5.7 & 16.2 & 63.2 & 0.747 \\
\hline N3I1 & 2.5 & 59.1 & 15.8 & 25.1 & 6.7 & 12.7 & 61.2 & 0.787 \\
\hline N3I2 & 2.3 & 58.3 & 13.7 & 28.0 & 4.3 & 17.3 & 54.8 & 0.144 \\
\hline N3I3 & 0.9 & 38.3 & 26.5 & 35.2 & 3.7 & 10.8 & 52.0 & 0.470 \\
\hline N4II & 0.9 & 54.9 & 31.0 & 14.1 & 6.8 & 12.5 & 35.3 & 0.101 \\
\hline N4I2 & 0.3 & 52.0 & 34.4 & 13.6 & 5.0 & 9.5 & 42.5 & 0.080 \\
\hline N4I3 & 2.2 & 57.9 & 12.6 & 29.5 & 4.9 & 13.8 & 55.4 & 0.273 \\
\hline
\end{tabular}
estimates were obtained from actual data (Table 2).

Table 3. Refined RUSLE model variables used in the sensitivity analysis.

\begin{tabular}{lll}
\hline \hline Notation & Description & Units \\
\hline A & estimated soil loss & $t /$ ha \\
a & organic matter content & $\%$ \\
b & soil structure index & - \\
c & profile permeability index & - \\
FC & plant canopy cover & (proportion) \\
H & canopy height & $\mathrm{m}$ \\
PC & soil clay content & $\%$ \\
RB & random roughness of the soil & mm \\
VL & live and dead vegetation cover & (proportion) \\
R & surface gravel cover & (proportion) \\
VFS & silt and very fine sand & $\%$ \\
SL & slope steepness and slope length & (dimensionless) \\
RS* & factor & $\mathrm{kg} /$ ha \\
\hline *RS was estimated using Weltz et al. (1987) equation: \\
RS $=$ BIO* ni * $\alpha$ i 100,
\end{tabular}

Statistical distributions (normal, uniform, and triangular) were assigned to 12 variables of the RUSLE model (Table 4). Values for the variables were sampled within their assigned distributions using 500 iterations of the Monte Carlo process (Tiwari and Hobbie 1976, Swartzman and Kaluzny 1987). A normal distribution was assigned to variables for which sufficient data were available to

Table 2. Summary of hydrologic data from Johnson and Gordon's (1988) rainfall simulation and erosion study on a sagebrush-grassland range site (Idaho) used to evaluate the RSC subfactor.

$\mathrm{N} \mathrm{N}=$ location, 11 = interspace plot number.

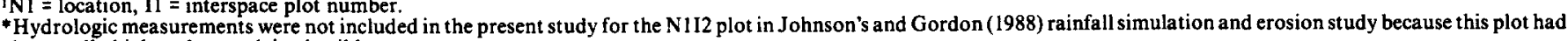
abnormally high and unexplained soil losses. 
Table 4. Values that defined normal, uniform, and rectangular distributions for each refined RUSLE model variable used in the sensitivity analysis.

\begin{tabular}{|c|c|c|c|c|c|c|c|}
\hline \multirow[b]{3}{*}{ Parameter } & \multicolumn{7}{|c|}{ Distribution assigned to model variables } \\
\hline & \multicolumn{2}{|c|}{ Normal } & \multicolumn{2}{|c|}{ Uniform } & \multicolumn{3}{|c|}{ Triangular } \\
\hline & Mean & $\mathrm{SD}$ & Min & $\operatorname{Max}$ & Min & Mode & $\operatorname{Max}$ \\
\hline $\mathrm{a}(\%)$ & & & 1.26 & 2.34 & & & \\
\hline$b$ index & & & & & 2 & 3 & 4 \\
\hline c index & & & & & 2 & 3 & 4 \\
\hline FC (prop.)! & 0.40 & 0.38 & & & & & \\
\hline $\mathrm{H}(\mathrm{m})$ & 0.15 & 0.05 & & & & & \\
\hline $\mathrm{PC}(\%)$ & & & 10 & 20 & & & \\
\hline $\mathrm{RB}(\mathrm{mm})$ & 12.60 & 3.78 & & & & & \\
\hline VL (prop.) & 0.55 & 0.17 & & & & & \\
\hline$R$ (prop.) & 0.16 & 0.05 & & & & & \\
\hline VFS $(\%)$ & & & 50 & 72 & & & \\
\hline $\mathrm{RS}(\mathrm{kg} / \mathrm{ha})$ & & & & & 38 & 55 & 72 \\
\hline SL (dimensionless) & 0.44 & 0.13 & & & & & \\
\hline
\end{tabular}

IProp. = proportion.

estimate mean and variance. A uniform distribution was assigned to variables for which available data provided only a range of values. A triangular distribution was assigned to soil structure and soil permeability classes for which only 1 value was available. Variation in variable values was created using $\pm 30 \%$ of actual mean values.

Partial correlation coefficients, between simulated variable values and simulated soil loss, were used as criteria to measure the sensitivity of the model prediction of soil loss to changes in a variable value after removing all the effects of the other variables (Rose 1983, Swartzman and Kaluzny 1987).

Correlation and graphical evaluation methods were used to compare original RUSLE predictions of soil loss with those simulated by RUSLE using the refined surface cover subfactor (RSC) (Benkobi et al. 1993). Predicted values from both simulations were then compared with actual field measurements of soil loss from this sagebrush-grass rangeland erosion study by Johnson and Gordon (1988) to determine if RSC improved predictability of RUSLE for a rangeland watershed.

\section{Results and Discussion}

Sensitivity of predicted soil loss to variations in model variables was determined by measuring the degree of dependence between soil loss and input variables using partial correlation coefficients (Table 5). Model predictions of soil loss were found to be sensitive to variations in slope steepness and slope length factor (SL). A partial correlation coefficient $(r)$ of +0.90 between predicted soil loss and data for slope length factor was obtained. Soil loss increased as slope steepness and slope length factor increased, as anticipated.

Simulated soil loss sensitivity to the cover and management factor (C) was associated with surface cover, surface roughness, and belowground biomass variables. Among the surface cover variables, vegetation cover (VL) accounted for most of the variation in soil loss $(r=-\mathbf{0 . 8 8})$. Soil loss decreased as the amount of vegetation cover increased. This result was anticipated. Rock cover (R) had a moderate correlation with soil loss $(r=-0.42)$. Jennings and Jarret (1985) found that rock cover was the least effective erosion control mulch material examined. However, Box (1981), Meyer et al. (1972), and Simanton et al. (1985) found better negative correlations between soil loss and rock cover.

Soil loss was also sensitive to surface random roughness (RB) $(r$ $=-0.67)$ and to the belowground biomass in the upper $10 \mathrm{~cm}$ of soil (RS) $(r=-0.50)$ (Table 5). Increased surface roughness resulted in
Table 5. Summary of sensitivity analysis measures as indicated by the partial correlation coefficient $(r)$ between simulated soil loss and refined RUSLE model variables ( $P=0.05)$.

\begin{tabular}{llc}
\hline \hline & Variable & r \\
\hline SL & slope steepness and slope length & +10.90 \\
& factor & \\
VL & vegetation material cover (prop.) & -0.88 \\
RB & random roughness (mm) & -0.68 \\
RS & root biomass (kg/ha) & -0.50 \\
R & rock cover (prop.) & -0.42 \\
b & soil structure class (index) & +0.20 \\
a & soil organic matter content (\%) & -0.17 \\
c & soil permeability class & +0.15 \\
PC & percentage clay (\%) & +0.10 \\
FC & plant canopy cover (prop.) & -0.10 \\
H & plant canopy height (m) & -0.06 \\
VFS & very fine sand plus silt (\%) & 0 \\
\hline
\end{tabular}

$1+=$ positive linear relationship with simulated soil loss.

$=$ negative linear relationship with simulates soil loss.

reduced soil loss. This was because runoff velocity and sediment transport were affected by depressions and mulch on the soil surface. When a soil surface is smooth, soil erosion may be considerable. Roots in the surface soil reduced erosion probably by increasing the resistance of the soil to overland flow by binding the soil mass with fibrous roots. In this simulation study, as random roughness and belowground biomass values increased, soil loss decreased.

Plant canopy cover (FC) and canopy height (H) had little effect on simulated soil loss ( $r=-0.10$ for FC, and $r=0$ for $\mathrm{H})$ in this study. The reason why plant canopy cover was not very important is probably because the sparse vegetation canopy did not absorb much energy from falling raindrops. However, soil surface cover was important. Khan et al. (1988) reported that plant canopy cover became less effective in reducing erosion when mulch was present on the soil surface. Simanton et al. (1991) found similar results when they studied direct and indirect effects of plant canopy cover on soil erosion and runoff.

Soil loss was not very sensitive to soil erodibility variables $(a, b$, c, $\mathrm{PC}$, and VFS) (Table 5). Among these variables, organic matter content (a) was the only variable that had a negative correlation with simulated soil loss $(r=-0.17)$. The soils permeability class (c) and soil structure class $(b)$ had little effect on simulated soils loss $(r$ $=+0.15$ for $\mathrm{c}$, and +0.20 for $\mathrm{b}$ ). The percentage of silt plus very fine sand (VFS) had no effect on simulated soil loss in this study. Probably, its effect on soils loss may have been partially accounted for in the $\mathrm{c}$ and $\mathrm{b}$ variables. Soil loss increased as soil structure and soil permeability deteriorated, as anticipated. Clay content (PC) had very little effect on simulated soil loss $(r=+0.10)$. Increases in clay content tended to reduce infiltration and, thus, increased runoff and erosion. An increase in organic matter contributes to increased porosity and infiltration rates that, in turn, reduce runoff and soil loss (Meeuwig 1970, Blackburn 1975, Blackburn et al. 1982).

Model predictions of soil loss were compared with actual field data from Johnson and Gordon (1988) using a simple linear correlation technique. The coefficients of determination $\left(r^{2}\right)$ obtained were 0.81 for dry conditions, and 0.50 for moist conditions for the refined RUSLE; and 0.67 for dry conditions, and 0.14 for moist conditions for the original RUSLE model (Fig. 1). The refined RUSLE predictions of soil loss described Johnson and Gordon's (1988) erosion data much better than did predictions from the original RUSLE model. However, predictions of soil loss were still low, even when the refined RUSLE model was used. This was particularly true at higher rates of erosion. 
a

Original RUSLE

Dry

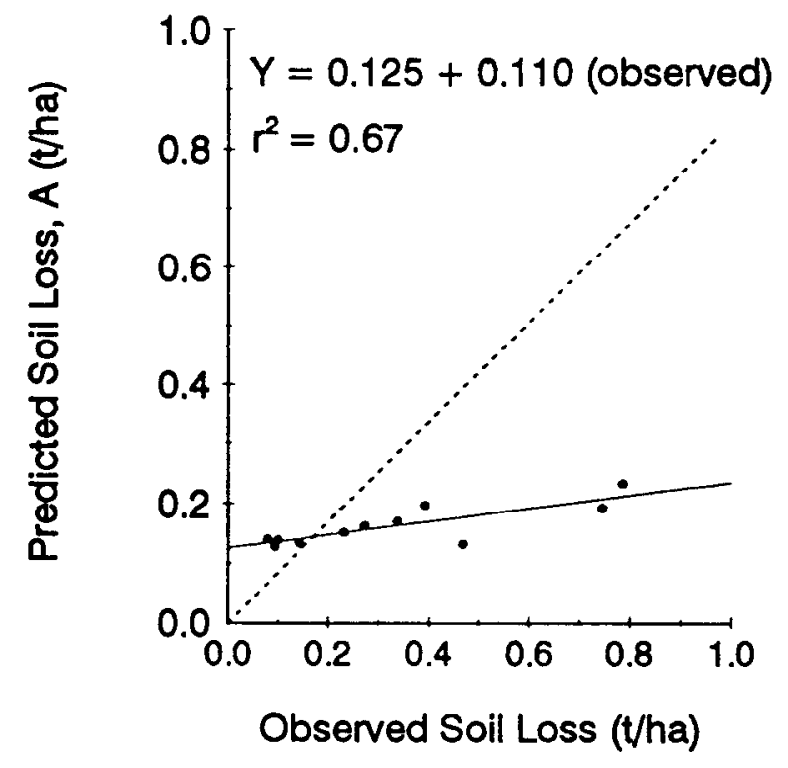

c

Original RUSLE

Wet

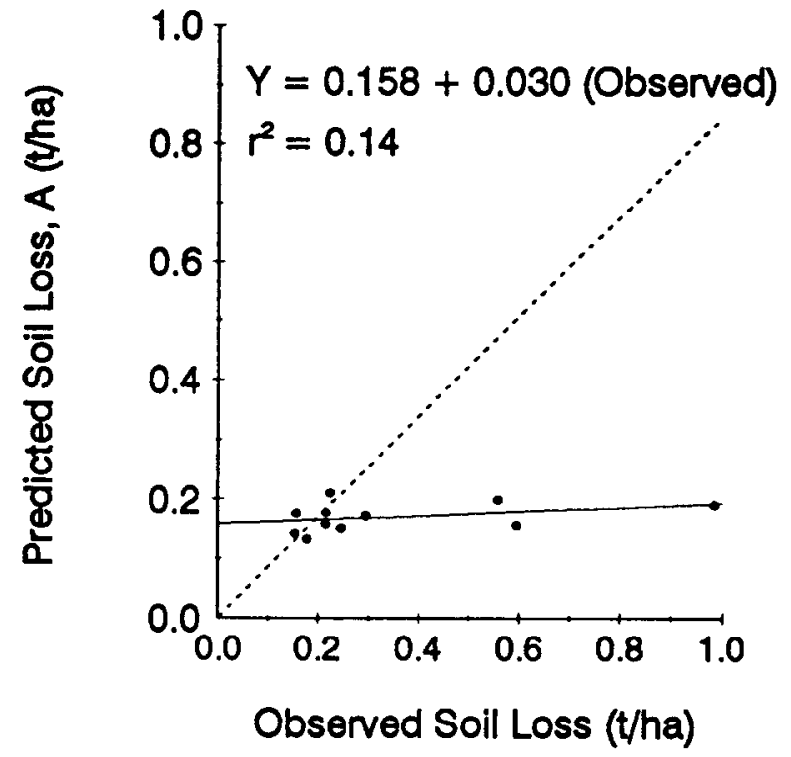

Refined RUSLE

Dry

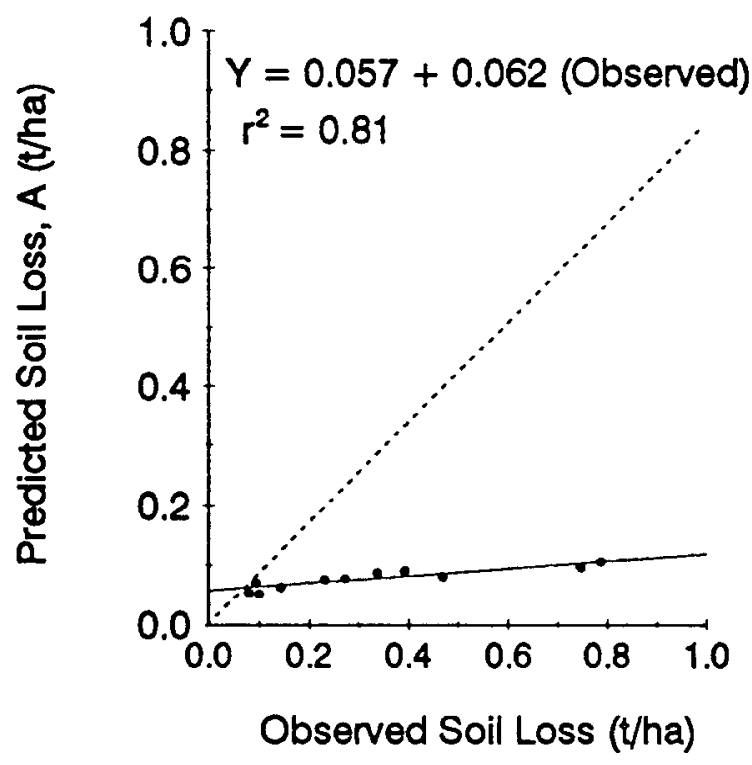

d

Refined RUSLE

Wet

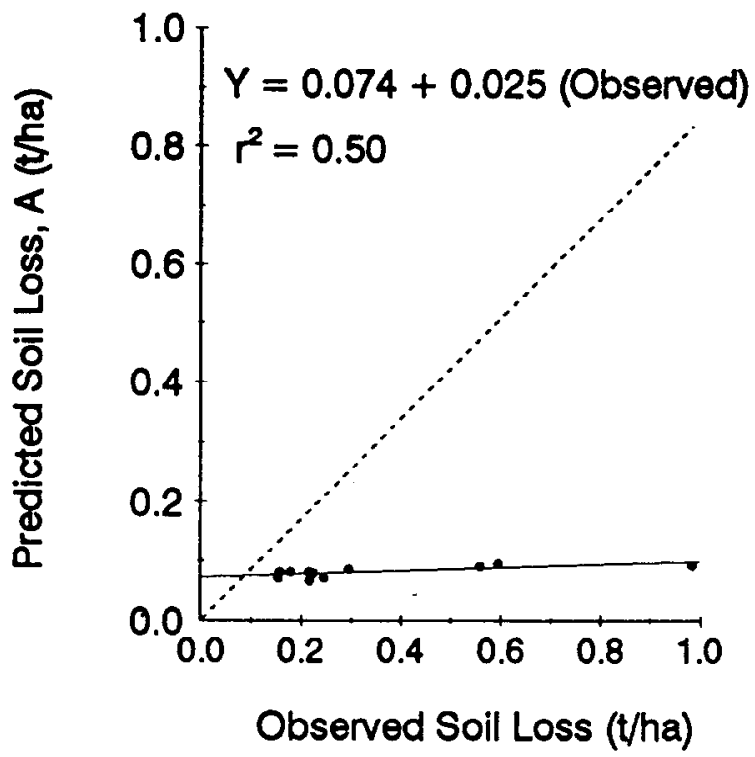

Fig. 1. Observed soil loss from erosion study plots (Reynolds Creek Watershed, Ida.) (Johnson and Gordon 1988) plotted against original RUSLE predictions $(\bullet)$ for soil loss under dry (a) and wet conditions (c), and as compared with predicted soll loss ( $\bullet$ ) using the refined RUSLE modei under dry (b) and wet conditions (d). Perfect model predictions of soil loss as compared with observed soil loss would fit the dashed line (--) in each graph. 


\section{Conclusions}

The refined RUSLE model was better at describing soil loss from Johnson and Gordon (1988) erosion plots on sagebrush-grass rangeland than was the original RUSLE model. The newly developed equation (RSC) considers more surface cover variables as they affect soil loss than does the original equation. The correlation between actual field data for soil loss and model estimations of soil loss was better when RSC was used instead of SC in the RUSLE model.

Simulated soil loss was most sensitive to changes in values of the slope steepness and slope length factor. Changes in surface cover, roughness and belowground biomass values also had significant effects on soil loss.

The ability of the refined RUSLE to simulate actual soil loss from rangeland was not completely tested in the present study, because small erosion plots may not represent erosion as measured by large erosion plots. Further model testing with field data from large erosion plots is needed before practical application of the refined RUSLE model on rangeland watersheds can be made. However, inclusion of more variables in the revised equation (RSC) appears to be beneficial in predicting erosion on rangelands.

\section{Literature Cited}

Benkobi, L., M.J. Trlica, and J.L. Smith. 1993. Soil loss as affected by different combinations of surface litter and rock. J. Environ. Qual. 22:657-661.

Blackburn, W.H. 1975. Factors influencing infiltration and sediment production of semi-arid rangelands in Nevada. Water Resour. Res. 11:729-737.

Blackburn, W.H., R.W. Knight, and M.K. Wood.1982. Impacts of grazing on watersheds. Texas Agr. Exp. Sta. MP-1496.

Box, J.E., Jr. 1981. The effects of surface slaty fragments on soil erosion by water. Soil Sci. Soc. Amer. J. 45:111-116.

Branson, F.A., G.F. Gifford, K.G. Renard, and R.F. Hadley. 1981. Rangeland Hydrology. Range Sci. Series No. 1, (2nd ed.), Soc. Range Manage., Denver, Colo.

Foster, G.R. 1982. Relation of USLE factors to erosion on rangelands. p. 17-35. In: Proc. Workshop on Estimating Erosion and Sediment Yield on Rangelands. USDA-ARS, ARM-W 26. Tucson, Ariz.

Hart, G.E. 1984. Erosion from simulated rainfall on mountain rangeland in Utah. J. Soil Water Conserv. 39:330-334.

Jennings, G.D., and A.R. Jarret. 1985. Laboratory evaluation of mulches in reducing erosion. Trans. ASAE. 28:1466-1470.
Johnson, C.W., G.A. Schumaker, and J.P. Smith. 1980. Effects of grazing and sagebrush control on potential erosion. J. Range Manage. 33:451-454.

Johnson, C.W., M.R. Savadi, and S.A. Loomis. 1984. Rangeland erosion measurements for the USLE. Trans. ASAE 27:1313-1320.

Johnson, C.W., and N.D. Gordon. 1988. Runoff and erosion from rainfall simulator plots on sagebrush rangeland. Trans. ASAE 31:421-427.

Khan, M.J., E.J. Monke, and G.R. Foster. 1988. Mulch cover and canopy effect on soil loss. Trans. ASAE 31:705-711.

Meeuwig, R.0. 1970. Infiltration and soil erosion as influenced by vegetation and soil in northern Utah. J. Range Manage. 23:185-188.

Meyer, L.D., C.B. Johnson, and G.R. Foster. 1972. Stone and woodchip mulches for erosion control on construction sites. J. Soil Water Conserv. 27:264-269.

O Neill, R.V., R.H. Gardner, and J.H. Carney. 1982. Parameter constraints in a stream ecosystem model: incorporation of a priori information in Monte Carlo error analysis. Ecol. Modelling 16:51-65.

Renard, K.G., and J.R. Simanton. 1990. Application of RUSLE to rangelands. p. 164-173. In: R.E. Riggins, E.B. Jones, R. Singh, and P.A. Rechard (eds.) Watershed planning and analysis in action. Amer. Soc. Civ. Eng., N.Y.

Rose, K.A. 1983. A simulation comparison and evaluation of parameter sensitivity methods applicable to large models. p. 129-140. In: W.K. Lauenroth, G.V. Skogerboe, and M. Flug (eds.) Analysis of ecological systems: State-of-the-art in ecological modelling. Elsevier Sci. Pub. Co. Inc., Oxford, N.Y.

Sartz, R.S., and D.N. Tolsted. 1974. Effects of grazing on runoff from two small watersheds in southwestern Wisconsin. Water Resour. Res. 10:354-356.

Schroeder, S.A. 1989. Soil loss comparisons between reclaimed stripmined and undisturbed grasslands in North Dakota. J. Environ. Qual. 18:30-34.

Simanton, J.R., E. Rawitz, and E.D. Shirley. 1985. Effects of rock fragments on erosion of semiarid rangelands soils. p. 65-72. In: S.A. El Swaify, W.C. Moldenhauer, and A. Lo (eds.) Soil erosion and conservation. Soil Conserv. Soc. Amer., Ankey, Iowa.

Simanton, J.R., M.A. Weltz, and H.D. Larsen. 1991. Rangeland experiments to parameterize the water erosion prediction project mode: vegetation canopy cover effects. J. Range Manage. 44:276-282.

Swatzman, G.L., and S.P. Kaluzny. 1987. Ecological simulation primer. Macmillan Co., N.Y.

Tiwari, J.L., and J.E. Hobbie. 1976. Random differential equations as models of ecosystems. Monte Carlo simulation approach. Math. Biosci. 28:25-44.

Trieste, D.J., and G.F. Gifford. 1980. Application of the universal soil loss equation to rangeland on a per-storm basis. J. Range Manage. 33:66-70.

Weltz, M.A., K.G. Renard, and J.R. Simanton. 1987. Revised universal soil loss equation for western rangelands. p. 104-111. In: Symp. Strategies for Classification and Management of Native Vegetation for Food Production in Arid Zones. USDA-GTR, RM-150. Tucson, Ariz.

Wischmeier, W.H., and D.D. Smith. 1978. Predicting rainfall erosion losses from cropland. USDA (in cooperation with Purdue Agr. Exp. Sta.) Handb. 537. 